\title{
PENETAPAN KADAR ETANOL PADA TAPE KETAN \\ PUTIH YANG TELAH DIFERMENTASI PADA \\ HARI KE 4, 5, DAN 6
}

\author{
Sediarso $^{1)}$, *Masdianto ${ }^{1)}$, Wisnu Rohmatulloh ${ }^{1)}$ \\ ${ }^{1}$ Program Studi Analis Kesehatan, Fakultas Kesehatan, Universitas Mohammad Husni Thamrin \\ Correspondence author: Masdianto, gene234@gmail.com, Jakarta, Indonesia
}

\begin{abstract}
ABSTRAK
Tape merupakan salah satu makanan tradisional Indonesia yang dibuat dengan cara fermentasi. Sebagai makanan hasil fermentasi, tape ketan putih memiliki cita rasa yang sangat khas, yaitu rasa asam manis dengan aroma alkohol. Jika kadar alkohol pada tape ketan hitam tinggi, maka tape akan terasa asam. Hal ini dapat terjadi karena waktu penyimpanan yang terlalu lama. Penelitian ini bertujuan untuk mengetahui kadar etanol yang didapatkan pada tape ketan putih yang difermentasi pada hari ke 4, 5, dan hari ke 6,penelitian ini menggunakan metode Gravimetri. Analisis gravimetri, atau analisis kuantitatif berdasarkan bobot adalah proses isolasi serta penimbangan suatu unsur atau suatu senyawa tertentu dari unsur tersebut, dalam bentuk yang semurni mungkin. Berdasarkan hasil penelitian, dapat diketahui bahwa kadar etanol pada hari ke 4 sebesar 6,39\%, hari ke 5 sebesar 8,22\% dan hari ke 6 sebesar 9,74\%. Berdasarkan hasil uji statistik One-way Anova didapatkan hasil P. Value 0,009 hal ini menunjukan adanya perbedaan yang bermakna. Kesimpulan yang diperoleh dari penelitian ini adalah kenaikan kadar etanol yang dipengaruhi oleh lamanya waktu fermentasi.
\end{abstract}

Kata kunci $\quad$ : Tape ketan putih, Etanol, Destilasi

\section{ABSTRACT}

Tape is a traditional Indonesian food made by fermentation. As a fermented food, white sticky rice has a very distinctive taste, which is a sweet and sour taste with an alcoholic aroma. If the alcohol content on the black sticky tape is high, the tape will taste sour. This can happen because the storage time is too long. This study aims to determine the ethanol content obtained in fermented white sticky rice on the 4th, 5th, and 6th day. This study uses the Gravimetric method. Gravimetric analysis, or quantitative analysis based on weight, is the process of isolating and weighing an element or a particular compound from that element, in the purest possible form. Based on the results of the study, it can be seen that the ethanol content on day 4 was $6.39 \%$, day 5 was $8.22 \%$ and day 6 was $9.74 \%$. Based on the results of the One-way Anova statistical test, the P. Value is 0.009 , this shows a significant difference. The conclusion from this research is that the increase in ethanol content is influenced by the length of fermentation time.

Key words: White glutinous tape, Ethanol, Distillation

Open Journal System (OJS): journal.thamrin.ac.id

http://journal.thamrin.ac.id/index.php/anakes/issue/view/35 


\section{PENDAHULUAN}

Tape merupakan pangan tradisional di Indonesia dan sangat digemari karena cita rasa manis, alkoholis, dan asam. Tape tidak asing lagi dengan nama tape telo di Jawa, peuyem di Bandung (Sunda) serta, bervariasi tergantung bahan dasar yang digunakan misalnya tape beras, beras ketan putih, ketan hitam, dan tape singkong. (Suaniti, 2015)

Tape merupakan salah satu makanan yang mengandung zat-zat gizi dan atau unsur-unsur zat kimia yang dapat diubah menjadi zat gizi oleh tubuh yang status gizinya dapat bersifat gizi buruk, kurang, baik, dan lebih (Almatsier, 2006 :17).

Proses fermentasi merupakan hidrolisis pati menjadi glukosa dan sebagian glukosa diubah menjadi alkohol. Proses fermentasi tape melibatkan penambahan mikroorganisme untuk membuat beras ketan menjadi produk yang diinginkan. Mikroorganisme yang biasanya digunakan adalah ragi. Ragi merupakan khamir (Saccharomyces cerevisiae) yang berfungsi untuk mengubah karbohidrat (pati) menjadi gula dan alkohol. Proses tersebut juga menyebabkan tekstur tape menjadi lunak dan empuk. Khamir adalah salah satu jenis mikroba yang sebenarnya banyak berperan dalam dunia pangan, tetapi kurang dikenal luas oleh masyarakat. Khamir memiliki peranan yang penting dalam proses pembuatan tape, yaitu mengubah pati pada singkong atau beras ketan menjadi gula, serta mengubah sebagian gula menjadi alkohol dan komponen flavor. (Johan W. von Mollendorff (2008:14).

Karbohidrat (glukosa) sebagai zat-zat esensial yang diperlukan oleh tubuh serta sebaliknya dalam jumlah berlebih juga tidak baik bagi kesehatan tubuh. Hal yang sama bila gula difermentasi menjadi alkohol, yang dalam jumlah secukupnya dapat melarutkan lemak tubuh tetapi dalam berlebihan sangat tidak baik bagi tubuh sehingga alkohol dianggap toksik atau racun (Almatsier, 2006:18).

Salah satu faktor yang berpengaruh dalam proses fermentasi adalah waktu fermentasi. Semakin lama waktu fermentasi maka semakin banyak gula yang diubah menjadi alkohol (etanol) oleh khamir Saccharomyces cerevisiae. Selain waktu fermentasi, suhu juga merupakan faktor yang mempengaruhi proses fermentasi. Kecepatan fermentasi akan bertambah dengan kenaikan suhu sampai suhu optimum yaitu $28^{\circ} \mathrm{C}-32^{0} \mathrm{C}$. Jika suhu fermentasi rendah maka fermentasi akan berjalan lambat karena proses metabolisme menurun sehingga produk yang dihasilkan tidak maksimal (Noviyanti, 2013:14 - 15).

Berdasarkan reaksi kimia yang terjadi gula dapat dioksidasi menjadi alkohol atau etanol. Penelitian ini saya mengacu pada penelitian sebelumnya oleh Rizca Noviyanti tahun 2013 "Penetapan Kadar Etanol Pada Tape Ketan Hitam Pada Suhu Kamar selama 0,1,2,dan 3 hari”. Penulis tertarik untuk mengetahui berapa kadar etanol yang didapatkan pada tape ketan putih yang telah difermentasi pada hari ke 4,5, dan 6 . 


\section{METODE}

Penelitian ini dilaksanakan tahun 2019 di laboratorium kimia pangan Universitas M.H Thamrin. Penelitian ini dilaksanakan dari tanggal 07 Agustus sampai dengan tanggal 16 Agustus 2019. Pengambilan sampel dilakukan dengan membuat tape ketan putih sendiri dan diambil tape ketan putih yang telah difermentasi pada hari ke 4, 5, dan 6. Penelitian ini menggunakan sampel tape ketan putih yang telah difermentasi pada hari ke 4, 5, dan 6. Penetapan kadar etanol pada tape ketan putih dilakukan dengan metode destilasi.

\section{HASIL DAN PEMBAHASAN}

Hasil penelitian yang dilakukan terhadap sampel tape ketan putih yang difermentasi pada hari ke 4, 5, dan 6 didapatkan kadar etanol pada hari ke 4 adalah 6,39\%, hari ke 5 adalah 8,22\%, dan hari ke 6 adalah $9,74 \%$ (tabel 1)

Tabel 1.

Hasil penetapan kadar etanol pada tape ketan putih.

\begin{tabular}{cccc|}
\hline $\begin{array}{c}\text { Sampel } \\
\text { Ulangan }\end{array}$ & $\begin{array}{c}\text { Hari ke 4 } \\
\text { v/v } \%\end{array}$ & $\begin{array}{c}\text { Hari ke 5 } \\
\text { v/v \% }\end{array}$ & $\begin{array}{c}\text { Hari ke 6 } \\
\text { v/v } \%\end{array}$ \\
\hline 1 & $6,16 \%$ & $8,46 \%$ & $10,13 \%$ \\
\hline 2 & $6,61 \%$ & $7,98 \%$ & $9,34 \%$ \\
\hline Total & $12,77 \%$ & $16,44 \%$ & $19,47 \%$ \\
\hline Rata-rata & $6,39 \%$ & $8,22 \%$ & $9,74 \%$ \\
\hline
\end{tabular}

Data kadar etanol pada tape ketan putih yang telah difermentasi pada hari ke 4, 5, dan 6, diolah menggunakan metode statistik yaitu uji One-way Anova (tabel 2)

\section{Tabel 2.}

Uji Statistik One-way Anova.

\begin{tabular}{|c|c|c|c|c|c|c|}
\hline \multicolumn{7}{|c|}{ Kadar Statistik } \\
\hline & $\begin{array}{l}\text { Perlakuan } \\
\text { Fermentasi }\end{array}$ & $\mathrm{N}$ & Mean & $\begin{array}{c}\text { Std. } \\
\text { Devitation }\end{array}$ & $\begin{array}{l}\text { Std. Error } \\
\text { Mean }\end{array}$ & p. value \\
\hline \multirow{3}{*}{$\begin{array}{l}\text { Kadar } \\
\text { Etanol }\end{array}$} & Hari ke 4 & 2 & 6,3850 & .31820 & 22500 & 0,009 \\
\hline & Hari ke 5 & 2 & 8,2200 & .33941 & 24000 & \\
\hline & Hari ke 6 & 2 & 9,7350 & .55861 & .39500 & \\
\hline
\end{tabular}

Hasil perbandingan kadar etanol yang telah difermentasi pada hari ke 4, 5, dan 6 menggunakan Statistik One-way Anova didapatkan nilai P. value 0,009, hal ini menunjukan ada perbedaan bermakna pada tape ketan putih yang difermentasi pada hari ke 4, 5, dan 6.

Pada penelitian ini kadar etanol pada hari ke 4 didapatkan hasil 6,39\%, hari ke 5 yaitu 8,22\%, dan hari ke 6 sebesar 9,74\%. Hasil tersebut menunjukan adanya kenaikan kadar etanol yang dipengaruhi oleh lamanya waktu fermentasi. 
Berdasarkan Peraturan Kementrian Badan Pengawas Obat Dan Makan Nomber 14 tahun 2016, kadar etanol yang didapat pada tape ketan putih termasuk Alkohol golongan B dengan kadar $5-20 \%$.

Berdasarkan hasil uji satistik one-way anova kadar etanol pada tape katan putih yang telah difermentasi pada hari ke 4,5, dan 6 didapatkan hasil P. Value 0,009 hal ini menunjukan ada perbedaan yang bermakna pada perlakuan fermentasi hari ke 4, 5, dan 6, yang mana bila dilihat lebih lanjut hasil yang berbeda signifikan yaitu kadar etanol pada tape ketan putih yang difermentasi pada hari ke 4 dan hari ke 6 . Perbedaan waktu fermentasi mengakibatkan kadar etanol semakin meningkat.

Pada proses fermentasi, jumlah mikroba antara lain dipengaruhi oleh lama fermentasi yakni semakin lama fermentasi jumlah mikroba semakin banyak dan produksi etanol semakin tinggi. Menurut Prescot dan Daunn menunjukan bahwa adanya pengaruh lama fermentasi terhadap kadar etanol dalam tape. Pada selang waktu 1 - 7 hari kadar etanol dalam tape terus meningkat, sedangkan setelah 7 hari kadar etanol dalam tape menurun. Hal ini dikarenakan pada hari ke 7 ragi saccharomyces cerevisiae memasuki fase stasioner, fase ini jumlah mikroba yang hidup sebanding dengan jumlah mikroba yang mati. Dengan demikian semakin berkurang jumlah nutrisi saccharomyces cerevisiae dan substrat, sehingga saccharomyces cerevisiae akan semakin menurun dan tidak mampu memproduksi alkohol (Hasanah, Jannah, \& Fasya, 2013:68 - 79).

Konsumsi etanol sebaiknya tidak berlebih selain dapat menghilangkan kesadaran juga dapat menimbulkan dampak negatif bagi tubuh seperti menimbulkan rasa mual, memicu sakit kepala, merusak jaringan dalam tubuh. Mengkonsumsi Etanol berlebihan dan secara rutin juga dapat membuat jaringan tubuh rusak satu persatu.

Etanol juga dapat menimbulkan gangguan pada ginjal misalnya batu ginjal ataupun gagal ginjal. Ginjal akan sulit mengolah Etanol menjadi urine. Selain ginjal yang terganggu, hati atau liver juga akan mengalami gangguan bila mengkonsumsi Etanol berlebihan. Hati tidak dapat berfungsi dengan baik bila sudah mengalami gangguan dan ini berhubungan dengan kondisi kesehatan kita dalam waktu lama.

\section{SIMPULAN}

Pada penelitian ini kadar etanol pada hari ke 4 didapatkan hasil 6,39\%, hari ke 5 yaitu 8,22\%, dan hari ke 6 sebesar 9,74\%. Menurut Peraturan Kepala Badan Pengawas Obat dan Makanan Republik Indonesia Nomor 14 tahun 2016 Kadar etanol yang didapat pada tape ketan putih termasuk golongan B dengan kadar 5-20\%. Hasil uji statistika menggunakan One-way Anova didapatkan hasil P. Value 0,009 hal ini menunjukan ada perbedaan yang bermakna. 


\section{UCAPAN TERIMA KASIH}

Penulis mengucapkan terima kasih kepada Prodi D III Analis Kesehatan Universitas MH Thamrin berperan serta dalam penelitian ini.

\section{DAFTAR PUSTAKA}

1. Almatsier, S. 2006. Prinsip Dasar Ilmu Gizi.Jakarta: Gramedia.

2. Arsyat, N, M., 2001, Kamus Kimia (Arti Dan Penjelasan Istilah), Jakarta:

3. PT.Gramedia Pustaka Utama, hal 11, 93 dan 94.

4. Dwidjosaputro, D.,1998, Dasar-dasar Mikrobiologi, Universitas Brawijaya, Institut Teknologi Nasional Malang, hal 154.

5. Farmakope Indonesia edisi IV tahun 2014, hal 1765-1768

6. Haryadi, H. 2013. Analisa Kadar Alkohol Hasil Fermentasi Ketan dengan Metode Kromatografi Gas dan Uji Aktifitas Saccharomyces Cereviceae Secara Mikroskopis. Universitas Diponegoro Semarang. Skripsi.

7. Hasanah, H. 2008. Pengaruh Lama Fermentasi Terhadap Kadar Alkohol Tape ketan Hitam (Oryza Sativa L var forma glutinosa) dan Tape Singkong (Manihot utilussima Pohl). Univrsitas Islam Negeri Malang. skripsi

8. Irianto, K, 2006, Mikrobiologi: Menguak Dunia Mikroorganisme Jilid . 2,Bandung: CV. Yrama Widya, hal 214-215.

9. Mardoni, dkk., 2007, Perbandingan Metode Kromatografi Gas Dan Berat Jenis Pada Penetapan Kadar Etanol Dalam Minuman Anggur, http://www.usd.ac.id /06/publ_dosen/far/mardoni.pdfdiakses 18 Maret 2012 .

10. Mollendorff, Wilhelm J. 2008. Characterization of Bacteriocins Produced by Lactic Acid Bacteria From Fermented Beverages and Optimization of Starter Cultures. Thesis for the degree of Master of Science : Stellenbosch University

11. Noviyanti,R. 2013. Penetapan Kadar Etanol Pada Tape Ketan Hitam Yang Disimpan Pada Suhu Kamar Dan Suhu Pendingin Selama 0,1,2,3 Hari. Jakarta

12. Suaniti, N. M. (2015). Kadar Etanol dalam Tape Sebagai Hasil Fermentasi Beras Ketan ( Oryza sativa glutinosa ) dengan Saccaromyces cerevisiae. Virgin, 1(1), 16-19.

13. Susanto T.,1994, Teknologi Pengolahan Hasil Pertanian, Surabaya : PT. Bina Ilmu.

14. Steenis,V, dan Bloembergen,(2002). Flora Untuk Sekolah di Indonesia 117. Cetakan ke-8. PT Pradnya Pramita, Jakarta

15. Vogel. 1994. Kimia Analisis Kuantitatif Anorganik. Alih Bahasa P.Hadyana. a dan Setiono. L. Jakarta ; Buku kedokteran EGC. 